\title{
Biomimetic materials and design
}

\section{Bengisu, Murat}

Resumen: El campo interdisciplinario de la biomimética ha sido objeto de creciente atención en los últimos años. La comunidad científica e industrial entiende que el daño que hemos estado haciendo a la naturaleza puede ser resuelto por la naturaleza misma. El diseño biomimético también ha ido ganando impulso gracias a las nuevas investigaciones y tecnologías. La biomimética no se limita a la forma y la estética solamente, sino que también hace uso de una comprensión más profunda de los aspectos funcionales, procesos y sistemas encontrados en la naturaleza. Este artículo desarrolla cinco enfoques biomimé- ticos: imitación, inspiración, funcionalidad, basado en procesos y basado en ecosistemas. Los estudios de casos

Cuadernos del Centro de Estudios de Diseño y Comunicación N070

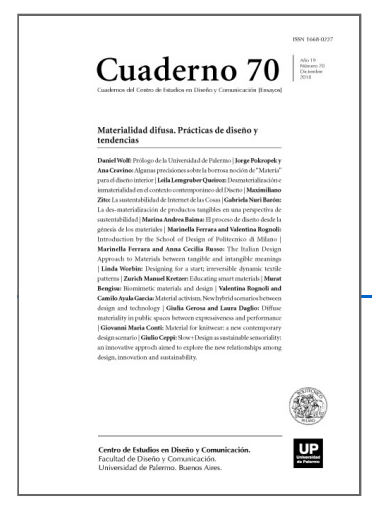

ISSN: 1668-0227

Materialidad difusa.

Prácticas de diseño y

tendencias

Año XIX, Diciembre 2018, Buenos Aires, Argentina | 172 páginas

descargar PDF ver índice de la publicación

Ver todos los libros de la publicación

compartir en Facebook

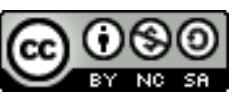
Esta obra está bajo una Licencia Creative Commons Atribución-NoComercialCompartirlgual 4.0 Internacional cortos explican cómo la investigación biomimética puede ayudar a resolver diferentes problemas en el diseño.

Palabras claves: Biomimética - materiales - bioinspiración - biofílica.

$\left(^{*}\right)$ M.S. and Ph.D. degrees in the field of Materials Science, New Mexico Tech, USA, is full professor at the Industrial Design Department at Izmir University of Economics (IUE). He teaches undergraduate courses about materials for design, manufacturing processes, ergonomics, design engineering, design studio, and graduate courses he developed for the Design Studies Master's and PhD Programs.

Introduction

Scientists and engineers have been working on biomimetic innovations since the 1970s. D'Arcy W. Thompson studied biological systems as engineering structures as early as 1917 (Torgal et al. 2015). The number of publications in the field of biomimetics has grown tremendously since the mid-1990s, reaching currently to about 3000 per year (Lepora et al. 2013). The interdisciplinary field of biomimetics aims to study biological materials, structures, and processes to develop similar materials, structures, or systems for human benefit. Various terms exist that have a similar meaning to biomimetics, including biomimesis, bio-inspired design, biomimicry, bionics, 
biophilic design, and biognosis (Vincent et al. 2006). One of the leading advocates of bioinspired problem solving is Janine Benyus. She has been promoting the idea of biomimicry since the 90 s through public talks, publications (Benyus, 1997; Benyus, 2008), and the Biomimicry Institute that she had founded in 2006. Biomimicry has been applied to many fields including energy generation, production, agriculture, engineering, information storage, and even business.

\section{Approaches for biomimetic design}

Before looking into some case studies, it would be useful to briefly analyze some of the approaches used in biomimetic design. Although the words biomimicry and biomimetic imply imitation of nature, they are normally not used in that sense. For example, Janine Benyus recommends a focus on function rather than form in biomimetic practice. Current engineering research also focuses mostly on function, as would be expected from its orientation towards end results, applications, new technologies, and new products. However, there is more than only form and function in biomimetics. The main approaches of biomimetic design could be listed as follows: imitation, inspiration, functional, processbased, and ecosystem-based.

The imitative approach tries to meticulously copy nature or real objects derived therefrom. A good example would be artificial flowers. Today, the level of sophistication in these products is so high that it is almost impossible to tell top quality artificial flowers apart from real ones, just by looking at them. However touching them spoils the magic because they are made of plastic or textile (although this may change in the near future as well). Sampuru (Japanese food models) are another interesting utilization of representation by faithfully copying the original item. These food models have been used in Japan since the 1920s in order to represent food items sold in cafeterias and restaurants, without the risk of spoiling the sample and having to throw it away each day (Lombardi \& Hashi, 2014). Earlier sampuru were made of wax but today they are made from durable polymers and they are crafted in such realistic detail that they look quite appetizing.

A second biomimetic approach is bioinspiration. Nature has always been an inspiration for artists and designers. Proof of this pattern can be found as early as the paleolithic era, depicted in cave paintings of animals such as cattle, horses, birds, and feline. One of the peak periods of inspiration for artists, architects, and designers was the Art Nouveau (Jugendstil) movement (1890-1910). This style emphasized organic forms and natural elements (Sağocak, 2003). The artistic illustrations of plants, animals, and marine creatures by German biologist Ernst Haeckel in his book Kunstformen der Natur (Art Forms of Nature, 1899-1904), posters, drawings, and oil paintings of the Czech artist Mucha, the famous organic-shaped buildings and furniture of Spanish architect Gaudi, and glass items designed by Émile Gallé in Nancy and Louis Comfort Tiffany in New York are just some examples from this brilliant period.

The main focus of biomimetic design research today is towards a functional one. This approach emphasizes functional problem solving based on benchmarks in nature. It involves careful analysis of the organism's innovative solutions to problems or environmental conditions, followed by skillfully adapting them using the designer's perspective. Some examples to this approach will be discussed under case studies (see Bloom, Fastskin, and water collection in arid regions inspired by the Stenocara beetle).

The process-based approach focuses on certain processes that occur through the participation of an organism or the ones that occur within the organism. For example, bone formation or osteogenesis occurs in all vertebrate 
including humans. A dynamic software program was developed based on stress optimization processes in trees and mass optimization processes in bones (Mattheck \& Tesari, 2002). Using this software, engineers of DaimlerChrysler reduced the weight of a new car that they designed, resulting in a mere 3,4 It/100km fuel consumption. This concept car was inspired by the shape of boxfish which inhabits coral-reefs. Designer Joris Laarman and his colleagues used a similar software developed at Opel to design chairs that optimize their strength to mass ratio replicating processes of bone growth. Repeated software simulations add material where more strength is required and remove material where it is not critical (Benyus, 2008). The aim of the process-based approach may be to realize a certain function or property as explained in this example (a lightweight but strong product) or to develop a new process as well (for example, a water purification process based on examples from nature).

Probably the most complex approach to apply in design is the ecosystem-based approach. This approach considers not only the designed product, building, landscape, or city, but it also takes into account how it is integrated with natural ecosystems and how it contributes to their regeneration (Pedersen Zari \& Storey, 2007). A recent pilot project presented at the Venice Architecture biennale in 2016 by Danish studio EFFEKT uses the ecosystembased approach at the scale of a village. The first ReGen village will be built in Almore, just outside Amsterdam. The aim of this project is to build a self-sustaining farm village. The village will apply sustainable organic farming in greenhouses, grow about half of the food the inhabitants need, and use high technology to generate green energy (Frearson, 2016). While the project has high hopes with regard to sustainability, time will show whether it will function as planned.

The approach-based categories are not absolute, but rather, they are intended to demonstrate that there are a multitude of options when learning from nature.

\section{Case studies}

Several projects have been accomplished by designers using biomimetic approaches and making use of biomimetic materials. It should be noted that the success of biological models and biomimetic counterparts discussed here are not only dependent on materials but also their micro- and nanoscale texture, morphology, arrangement, and functional strategy.

Architects and designers started to emphasize bioinspired approaches recently. For example, Sung (2016) used manganese-nickel bimetals as smart materials that respond to environmental temperature changes. Bloom is a pavilion designed by Sung and realized by combining approximately 14000 laser-cut bimetals (Figure 1). These bimetals respond to temperatures above $22^{\circ} \mathrm{C}$ by curling up and letting air to flow in and out of the façade. This installation demonstrates the feasibility of the concept which aims to balance internal heat accumulation in buildings with a biomimetic approach. Sung is an architect with a biology background. She was inspired by human skin that naturally regulates the temperature of the body (Sung, 2012).

Designer and chemist Lauren Bowker successfully commercialized several bioinspired fashion accessories including bags, wallets, and wrist straps. A team of anatomists, engineers, chemists, and designers designed and developed a collection of products under the title Unseen. The collection is composed of items that incorporate natural materials such as feathers, quills, and leather. These items change color depending on the environment. For instance, a leather bag changes color with a slight pressure, a scarf displays different patterns with changes in temperature, or a calligraphy quill flourishes a peacock color palette upon contact with air (TheUnseen, 2015). 
Badarnah and Kadri (2014) developed a methodology for the generation of biomimetic design concepts they called BioGen. Their methodology involves various steps including the definition of a design challenge, exploration and biophysical investigation, pinnacle analysis (analysis of organisms and natural systems that accomplish the desired function), abstraction via pinnacle analysis and design path matrices, generation of a design concept, and estimation of performance. Applying this process to the design challenge of collecting water in arid regions, storing it, and optionally humidifying and cooling an interior space, they adapted the morphological features of the elytra (fused overwings) of the Namib Desert beetle. The Stenocara beetle's elytra contain randomly distributed hydrophilic (water-loving) nonwaxy bumps surrounded by hydrophobic (waterrepelling) wax coated grooves (Figure 2). When the beetle tilts its back wings into the fog, microcondensation causes water droplets to collect on the bumps and the hydrophobic grooves channel the water droplets into the beetle's mouth (Garrod et al. 2007). The diffusion of collected water from the skin to the interior space in the design concept involves a fibrous material that attracts water via capillary action. This was inspired by the Thorny devil's semi tubular capillary system that allows transport of water to the mouth (Badarnah and Kadri, 2014). Designers at Philips developed Bio-light in collaboration with Dr. Maarten Merkx from the Eindhoven University of Technology. Bio-light is an experimental lighting system that makes use of bioluminescent bacteria found in organisms such as fireflies, glow-worms, and certain marine creatures. The system is composed of glass compartments containing a fluid that houses bacteria, a bio-digester unit that generates methane from composted bathroom solids and kitchen vegetable waste, and silicone tubes that carry methane from the biodigester to the glass compartments in order to feed the bacteria. Although the green luminescence is not bright enough to replace artificial lighting yet, some applications such as warning strips on curbs, exit signs for dark public spaces, and nighttime edge indicators for roads are envisioned. The system does not require any electricity, it is a sustainable solution since it converts household waste into domestic lighting, and has the potential of functioning for a very long time, as long as methane is fed to the bacteria (Jonsson, 2011).

Microscopic tooth-like scales of shark skin have ribs with longitudinal grooves (Figure 3 ) that result in a reduction of water drag by $5-10 \%$. In 2006 Speedo introduced the Fastskin swimsuit inspired by the texture and low drag coefficient of shark skin. The swimsuit used polyurethane woven fabric that incorporated built- in ridges to reduce drag and water turbulence around the body. A large number of world records broken by swimmers wearing this swimsuit suggest that the biomimetic design has been quite successful (Bhushan, 2009).

\section{Outlook}

Commonly most biomimetic materials research is intended for engineering applications but designers may also benefit from their unusual structure and properties. Based on this limited review, it can be said that biomimetic materials need to prove themselves or become commercialized before they are used by designers even in the conceptual stage. There are very few examples where designers or design teams are directly inspired from natural materials and apply them in a new design. This is probably what one should expect since designers are typically not well-equipped with materials science knowledge. To bypass commercialization of biomimetic materials and go directly from nature to biomimetic design using biomimetic materials, one approach could be to facilitate collaboration of designers with materials engineers.

As discussed above, various biomimetic projects have already been realized but there is still a vast ocean of possibilities to explore for designers. Particularly, there are many design opportunities with regard to processes such as self-assembly, mass-shape-strength optimization, and fractal growth. Materials with biomimetic capabilities of self-healing, responding to changes in environmental conditions, transport of light and matter, 
transformation, motion, and growth are worth exploring and developing for innovative design solutions. These biomimetic materials, processes, and designs will no doubt contribute to the solution of many environmental and social problems faced in our world today.

\section{References}

Badarnah, L. \& Kadri, U. (2014). A methodology for the generation of biomimetic design concepts. Architectural Science Review, 58(2), 120-133.

Benyus, J. M. (1997). Biomimicry. New York: William Morrow.

Benyus, J. (2008). A good place to settle: Biomimicry, biophila, and the return to nature's inspiration to architecture. Biophilic design: The theory, science, and practice of bringing buildings to life. Hoboken, NJ: Wiley.

Bhushan, B. (2009). Biomimetics: lessons from nature-an overview. Philosophical Transactions of the Royal Society of London A: Mathematical, Physical and Engineering Sciences, 367(1893), 1445-1486.

Frearson, A. (2016). EFFEKT designs villages that produce all food and energy. http://www. dezeen.com/2016/05/20/effekt-designs-regen-villages-produce-own-food-energydanish-pavilion-venicearchitecture-biennale-2016/ accessed 30.05.2016 Garrod, R. P.; Harris, L. G.; Schofield, W. C. E.; McGettrick, J.; Ward, L. J.; Teare, D. O. H. \& Badyal, J. P. S. (2007). Mimicking a stenocara beetle's back for microcondensation using plasmachemical patterned superhydrophobic-superhydrophilic surfaces. Langmuir, 23(2), 689-693.

Jonsson, R. (2011). Philips Bio-light concept lights the home using bacteria. http://www. gizmag.com/philips-biolight-concept-taps-bioluminescence-for-home-use/20632/ accessed 25.07.2016

Lepora, N. F.; Verschure, P. \& Prescott, T. J. (2013). The state of the art in biomimetics. Bioinspir. Biomim. 8 (2013) 1-11.

Lombardi, L. \& Hashi (2014). Sampuru: Japanese food models. https://www.tofugu.com/ japan/sampuru/ accessed 28.05.2016 Mattheck, C. \& Tesari, I. (2002). Integrating biological optimisation methods into engineering design process. Design and Nature, 27-36.

Nørgaard, T. \& Dacke, M. (2010). Fog-basking behaviour and water collection efficiency in Namib Desert Darkling beetles. Frontiers in zoology, 7(1), 18.

Pedersen Zari, M. \& Storey, J. B. (2007). An ecosystem based biomimetic theory for a regenerative built environment. In Sustainable Building Conference 07, Lisbon, Portugal.

Sağocak, M. (2003). Tasarım tarihi (design history). Bursa, Turkey: Vipaş.

Sung, D. (2016). Smart geometries for smart materials: taming thermobimetals to behave. Journal of Architectural Education, 70(1), 96-106. 
Sung, K. D. (2012). Metal that breathes, TEDxUSC http://www.ted.com/talks/doris_kim_ sung_metal_that_breathes, accessed 18.05.2016

TheUnseen (2015). TheUnseen Emporium. http://theunseenemporium.co.uk/ accessed 22 July 2016.

Torgal, J.A. F.P. et al. (2015). Biotechnologies and biomimetics for civil engineering. Heidelberg: Springer.

Vincent, J. F.; Bogatyreva, O. A.; Bogatyrev, N. R.; Bowyer, A. \& Pahl, A. K. (2006). Biomimetics: its practice and theory. Journal of the Royal Society Interface. 3(9), 471-482.

Abstract: The interdisciplinary field of biomimetics has been enjoying increasing attention in recent years. The scientific and industrial community understands that the harm we have been doing to nature can actually be solved by nature herself. Biomimetic design has also been gaining impetus thanks to new research and technologies. Biomimetics is not limited to form and aesthetics only but also makes use of a deeper understanding of functional aspects, processes and systems found in nature. This paper elaborates on five biomimetic approaches: imitation, inspiration, functional, process-based, and ecosystem-based. Short case studies explain how biomimetic research can help solve different problems in design.

Key words: Biomimetic - biomimicry - materials - bioinspiration - biophilic

Resumo: O campo interdisciplinar de biomimética tem recebido atenção crescente nos últimos anos. A comunidade científica e industrial entende que os danos que temos feito à natureza podem ser resolvidos pela própria natureza. O design biomimético também vem ganhando força graças a novas pesquisas e tecnologias. Biomimética não está limitado a apenas a forma e estética, mas também faz uso de uma compreensão mais profunda dos aspectos funcionais, processos e sistemas encontrados na natureza. Este artigo tem cinco abordagens biomiméticos: imitação, inspiração, funcionalidade, com base em processos e com base nos ecossistemas. Os estudos de caso explicam como a pesquisa biomimética pode ajudar a resolver problemas diferentes em design.

Palavras chave: biomimética - materiais - Bioinspiration - biophilic.

Biomimetic materials and design fue publicado de la página 97 a página103 en Cuadernos del Centro de Estudios de Diseño y Comunicación №70 